\title{
Local diffusion networks act as pathways to sustainable agriculture in the Sacramento River Valley
}

by Mark Lubell and Allan Fulton

Greater sustainability is one of the main goals of agricultural and natural resource policy in California and worldwide. "Diffusion networks," which consist mainly of connections among producers, local outreach and education agencies and agricultural organizations, provide critical pathways for achieving sustainability. We analyzed the role of diffusion networks in the context of agricultural water-quality management in the Sacramento River Valley. Data from a survey of more than 1,200 agricultural producers demonstrates the role of diffusion networks in increasing satisfaction with environmental policies, participation in water-quality management programs and the implementation of sustainable agricultural practices.

reater sustainability has become one Jof the primary goals of agricultural and natural resource policy in California and worldwide. Although there is certainly no consensus on the meaning of sustainability, most definitions include three principles: environmental health, economic viability and social equity (Brown et al. 1987; Schaller 1993).

Agricultural water-quality management is an excellent case study because it involves all three principles of sustainability. The goal is to reduce the potential negative environmental impacts of agricultural production while maintaining economic viability and considering the diversity of agricultural communities. Non-point-source pollution in storm-water runoff and irrigation return flows is the cumulative result of individual decisions made by all producers in a watershed. Therefore, reducing the environmental impacts of agriculture illustrates what we believe is a central challenge in sustainability:

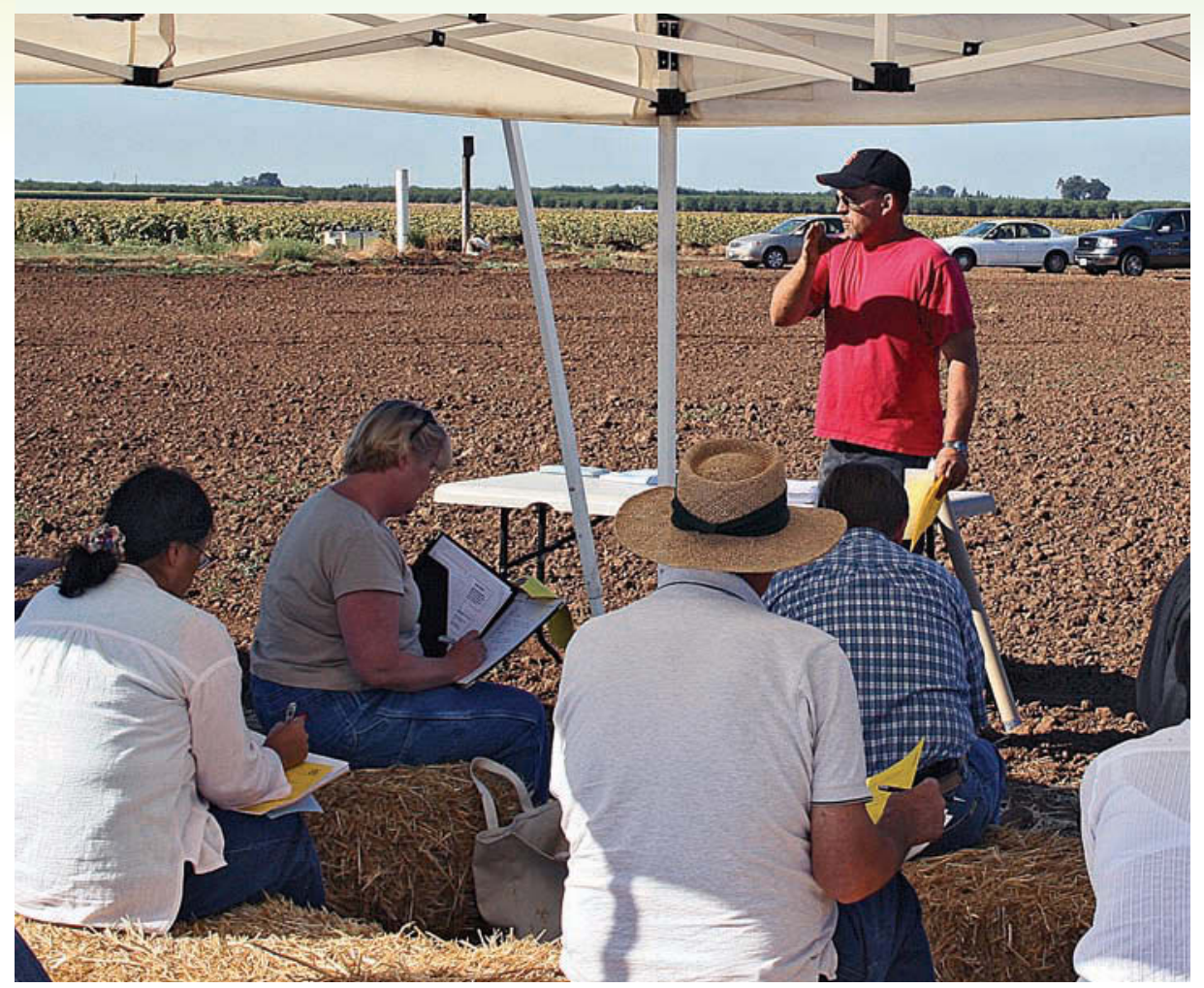

Formal and informal connections, called "diffusion networks," encourage growers in the Sacramento River Valley to implement new practices that improve water quality. At a field day in Chico, Allan Fulton shares information on the different methods available for managing tailwater runoff from irrigated fields.

understanding attitude change and encouraging cooperation among large numbers of individual resource users. This same challenge is seen in other sustainability issues, such as urban water conservation and global warming, where solutions will require large-scale collective action.

\section{Local diffusion networks}

We focus on the environmental aspect of sustainability, in the context of agricultural water-quality management in California's Sacramento River Valley. Our central thesis is that local "diffusion networks" - involving producers, local public agricultural agencies and private agricultural organizations - offer three potential pathways for achieving sustainability. These networks (1) provide information about innovations in agricultural practices, (2) act as a repository of social capital for solving collective dilemmas and (3) facilitate cultural change.
Information communication. Classic diffusion networks are defined as members of a social system that communicate information about agricultural practices and issues through formal and informal connections and interactions (Rogers 2003). Diffusion networks enable adoption decisions by spreading awareness about the costs and benefits of innovations. Recent studies focus on how the different structural characteristics of diffusion networks affect the rate and pattern of information flow (Conley and Udry 2001; Chiffoleau 2005). Diffusion processes were an important aspect of the post-World War II "Green Revolution," which featured the widespread, international adoption of new technologies to increase agricultural productivity (Evenson and Gollin 2003).

In the United States, diffusion networks have been evolving since the late 19 th century in the form of local special districts, commodity organizations and 

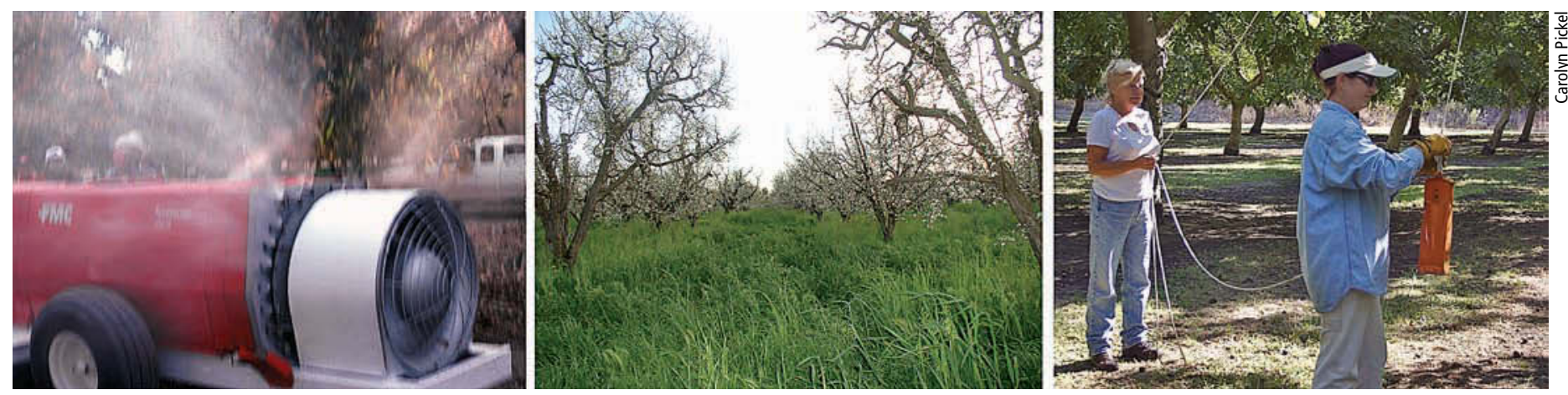

In a survey of Sacramento River Valley growers, nine different network contacts were needed for the addition of one best management practice (BMP) for water quality. Some BMPs used by producers included: left, a new lower-volume, targeted blast, orchard-sprayer (shown being demonstrated with water only); center, resident orchard vegetation to improve infiltration and reduce runoff; right, pheromone puffers hung in trees to manage insect pests.

government-supported education and outreach programs. Among the earliest examples are land-grant universities and their associated networks of county Cooperative Extension offices, which help deliver scientific research and knowledge to agricultural stakeholders. The Smith-Lever Act of 1914 established Cooperative Extension, roughly in conjunction with the California Farm Bureau Federation (Scheuring 1995).

Some agricultural practices contributing to the Green Revolution - such as pesticide use for improved crop protection, fertilizer applications for enhanced plant nutrition, and irrigation for more reliable crop performance - are now considered partial contributors to agricultural non-point-source pollution. To effectively address agricultural impacts on the environment and still maintain economically viable operations, greater sustainability will entail the adoption of more environmentally friendly, yet agronomically sound, best management practices (BMPs). Diffusion networks are playing a key role in delivering information about environmental issues and BMPs in an era when sustainability is increasingly emphasized.

Social capital. Diffusion networks are also an investment in social capital, which consists of interconnections within a community, norms of reciprocity and social trust (Ostrom 1994; Putnam 2000). Social capital is a critical resource for solving collective-action problems in which the costs and benefits of agricultural practices are influenced by the decisions of numerous producers. For example, one producer's water-quality management efforts will achieve only an incremental reduction in non-pointsource pollution. However, if producers who share a common interest in a water- shed work cooperatively to implement BMPs, the collective benefits to water quality will be greater. These collectiveaction problems are further complicated when some producers decline adoption and may be perceived to benefit (as "free riders") from the participation of others. Diffusion networks help agricultural stakeholders overcome these collective dilemmas to the extent that they serve as reservoirs of social capital and trust.

Cultural change. Finally, diffusion networks can also be pathways for cultural change and, more broadly, cultural evolution (Henrich 2001; Richerson and Boyd 2005). Theories of cultural evolution hypothesize that social learning from other people is a key mechanism of cultural change. Social learning occurs when one member of the social system makes decisions on the basis of the behavior of his or her peers. For example, some producers may observe and then follow the practices of the most successful operations in their community. Social learning may also involve processes of persuasion, where people in the group who have specific expertise in BMP development and water-quality management may actually change the preferences of other individuals. Importantly, diffusion networks provide information not only about a particular innovation, but also about the expertise and socioeconomic characteristics of other actors in the network.

Viewing diffusion networks as pathways to cultural change is particularly important in the case of water-quality management, where mitigating any identifiable non-point-source pollution depends on changes in the behaviors, attitudes and beliefs of the relevant agricultural community. Part of this change involves various government policies that reward preferred actions or penalize behavior that is defined as "unsustainable." But significant cultural change is more likely to occur when accompanied by the acceptance of new behaviors and norms throughout a community. Theories of cultural evolution emphasize the role of social learning and diffusion networks in gaining the acceptance of principles and policies of sustainability in agriculture (Richerson and Boyd 2005).

This article provides empirical evidence for the important role of diffusion networks in sustainable agriculture by describing how local agencies have facilitated participation in water-quality management. We focus specifically on the Sacramento Valley Water Quality Coalition (SVWQC), which emerged in response to new regulatory requirements passed by the Central Valley Regional Water Quality Control Board (Region 5 board). Using data from a survey of over 1,200 Sacramento River Valley producers, we show how diffusion networks have increased satisfaction with coalition policies, participation in coalition activities and the implementation of environmental BMPs.

\section{Sacramento River Valley study}

The Sacramento River Valley supports about 2,145,000 acres of irrigated land across 250 different drainage areas. About $85 \%$ of the irrigated land is on the valley floor and about 15\% is in nearby foothills and mountain valleys; about 65,100 acres are seasonal and permanent wetlands. More than 60 different crops are grown in the valley, primarily rice, orchards and irrigated pasture. Agricultural water-quality constituents of concern include pesticides, pathogens, sediment and nutrients, and physical pa- 


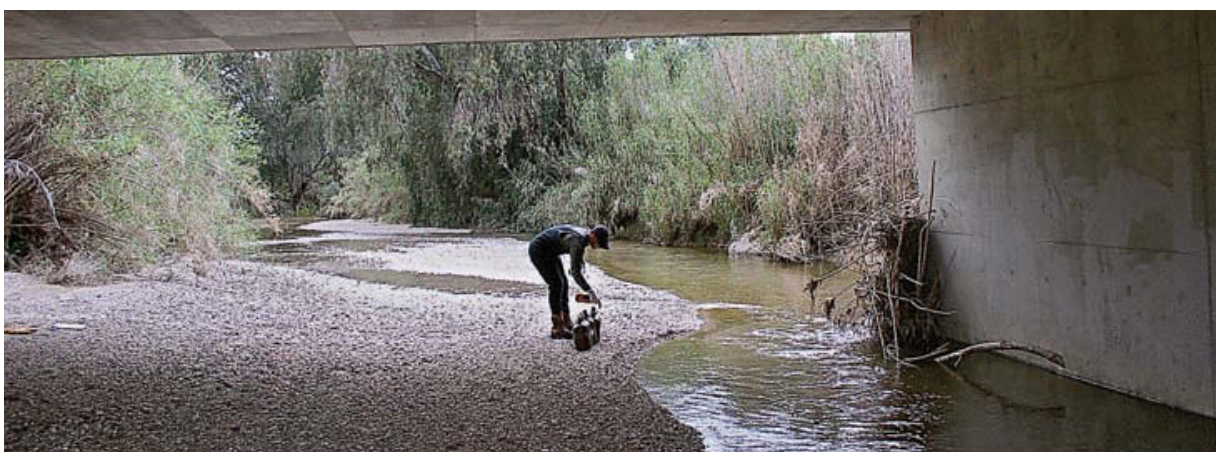

By joining a watershed management coalition, growers can work jointly to reduce non-pointsource pollution while meeting requirements of the Central Valley Regional Water Quality Control Board's "Conditional Waiver" program. A sample crew monitors water quality in a Tehama County waterway in accordance with the Conditional Waiver.

\section{Diffusion networks support three pathways that are essential to sustainability: information about innovations, social capital and cultural change.}

rameters such as temperature, dissolved oxygen and dissolved organic carbon. A total maximum daily load (TMDL) is in effect for diazinon insecticide on the Feather River from below Oroville Dam to the confluence of the Sacramento River. Additional TMDLs are being developed in the Delta and other Central Valley watersheds, targeting both urban and agricultural pollutants. Recent agricultural water-quality monitoring (under the Conditional Waiver, see below) has indicated relatively good surface water quality throughout the Sacramento River Valley with isolated areas of concern that may also be influenced by nonagricultural land uses.

Agricultural water-quality management has recently become a controversial topic in the Central Valley because of the so-called Conditional Waiver program, first adopted by the Region 5 (Central Valley) board on Jan. 1, 2003, and recently revised and extended into 2011 (CVRWQCB 2007). The waiver regulates non-point-source pollution by requiring irrigated agricultural producers to choose one of three options:

(1) join a watershed management coalition, an organized group of producers who work together to conduct waterquality monitoring and implement best management practices when problems associated with irrigated agriculture are found; (2) as an individual, request (from the Regional Board) coverage under the Conditional Waiver apart from a coalition; or (3) as an individual, submit a Request for Waste Discharge
Requirements from the Regional Board and then operate under a permit.

The majority of producers in the Sacramento River Valley have opted to join the SVWQC, the area's most encompassing watershed-management coalition, because it allows them to share the costs of the monitoring program, facilitates local oversight, takes advantage of local knowledge and is less intrusive on individuals. Such coalitions also focus on the watershed, attempt to consider the cumulative effects from multiple operations and try to integrate some of the elements of collaborative policy at the local level (Sabatier et al. 2005). However, some producers in the Sacramento River Valley have criticized the nonvoluntary nature of the program as an unnecessary regulatory burden.

The critical role of diffusion networks is illustrated by the SVWQC's nested watershed approach, which divides the larger watershed into 10 subwatershed groups, based on county and hydrological boundaries (fig. 1). The subwatershed groups are typically headquartered locally with organizations such as the county agricultural commissioner, the county farm bureau or a previously established watershed group. The subwatershed leadership collaborates with other local stakeholders, such as resource conservation districts, UC Cooperative Extension and the federal Natural Resource Conservation Service. The exact structure of the partnerships is different in each subwatershed, reflecting the unique configuration of

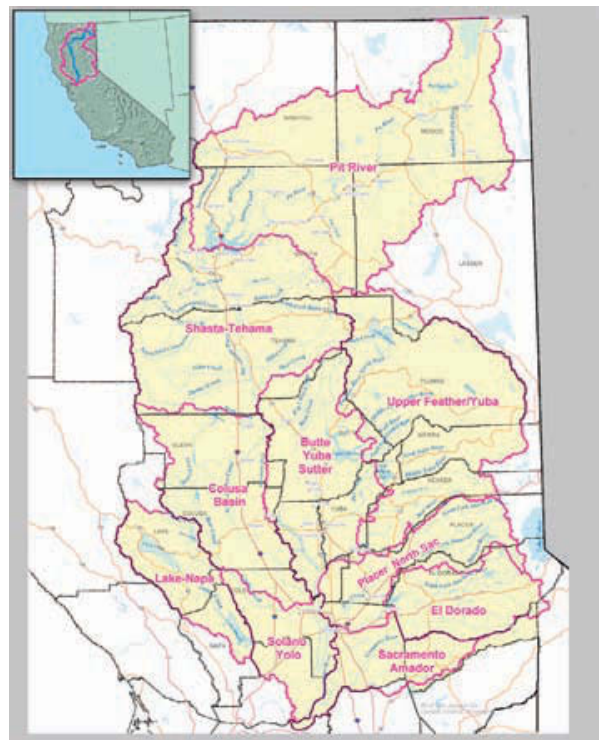

Fig. 1. Sacramento Valley Water Quality Coalition (SVWQC) subwatershed map. Source: Northern California Water Association/Ducks Unlimited.

networks, political interests, policy expertise, leadership and individual personalities in each area.

Regional coordination among the subwatershed groups is achieved by three main organizations: the Northern California Water Association (NCWA), Ducks Unlimited (DU) and the Coalition for Urban Rural Environmental Stewardship (CURES). These organizations ensure professional oversight of the water-quality monitoring program, and the timely preparation of required documents and reporting of water-quality monitoring results. The regional coordinators are headquartered in the Sacramento area and serve as a liaison between the Regional Board and producers in the more distant, rural areas of the Sacramento River Valley.

These networks of subwatershed and regional actors represent each of the three pathways for sustainable agriculture. They inform producers about the requirements of the program, opportunities for participation, and appropriate management practices for protecting and enhancing water quality. They are a main source of social capital and trust, and they help build interagency cooperation as well as encourage producer participation. They encourage cultural change by demonstrating the success of various water-quality programs and practices, as well as providing public awareness about individual producers who are outstanding examples of stewardship. Whether the Conditional 
TABLE 1: Sacramento River Valley farmers' use of water-quality management practices, 2004

\begin{tabular}{|c|c|}
\hline Practices & $\begin{array}{c}\text { Farmers } \\
\text { using } \\
\text { practice }\end{array}$ \\
\hline & $\%$ \\
\hline \multicolumn{2}{|l|}{ Conventional pest management } \\
\hline Base spray timing on weather/wind & 88.48 \\
\hline $\begin{array}{l}\text { Dispose of rinsate by mixing with water } \\
\text { and reapplying to orchard }\end{array}$ & 80.88 \\
\hline $\begin{array}{l}\text { Calibrate pesticide sprayers before every } \\
\text { application or more than once per year }\end{array}$ & 61.52 \\
\hline $\begin{array}{l}\text { Maintain setback/buffer zones when } \\
\text { spraying }\end{array}$ & 46.32 \\
\hline Check droplet/nozzle size on sprayer & 39.46 \\
\hline $\begin{array}{l}\text { Apply dormant sprays to treat problem } \\
\text { instead of as a preventive method* }\end{array}$ & 10.78 \\
\hline \multicolumn{2}{|l|}{ Alternative pest management } \\
\hline Provide beneficial insect habitat & 30.88 \\
\hline Use pheromone mating disruption & 17.65 \\
\hline Release beneficial insects in past 5 years & 10.78 \\
\hline \multicolumn{2}{|l|}{ Runoff control } \\
\hline $\begin{array}{l}\text { Plant filter strip between orchard } \\
\text { and waterway* }\end{array}$ & 50.25 \\
\hline $\begin{array}{l}\text { Use resident/planted vegetation } \\
\text { as cover crop }\end{array}$ & 36.52 \\
\hline \multicolumn{2}{|c|}{$\begin{array}{l}\text { * Percentages are based on two separate subsets of orchard } \\
\text { growers: those who indicated using dormant sprays every } \\
\text { year ( } 49 \% \text { of sample) and those who indicated that some of } \\
\text { their storm-water runoff drains into a waterway or drainage } \\
\text { ditch }(56 \%) \text {. Growers who did not use dormant sprays every } \\
\text { year }(51 \%) \text { or who said they have no runoff into waterways } \\
\text { (44\%) were not prompted to answer questions about } \\
\text { dormant-spray strategies or filter strips. To avoid deleting } \\
\text { these observations in table 3, we coded those respondents } \\
\text { who skipped the questions as not having the practice. }\end{array}$} \\
\hline
\end{tabular}

Waiver program is viewed as collaborative or regulatory policy, the diffusion networks involved with the SVWQC make a positive contribution to sustainability to the extent that they facilitate producer participation in water-quality management.

\section{Survey methods and respondents}

To examine the role of diffusion networks, we conducted a mail survey of 5,073 producers from nine Sacramento River Valley counties: Butte, Colusa, Glenn, Shasta, Solano, Sutter, Tehama, Yolo and Yuba. The sample list was constructed mainly from agricultural commissioner pesticide-permit lists. The standard Dillman (2000) methodology of delivery (introductory letter, survey package, reminder, second survey package, second reminder) was used to encourage response. The respondents were divided into a group of known orchard producers and a group of other producers for whom the specific commodities were not known beforehand (the nonspecific group). A 12-page survey was mailed to growers, which included 68 questions about their views on waterquality management, political values and farm characteristics; most of the responses were yes/no or 7-point Likert scales. The orchard respondents received several additional questions about orchard management practices.

The survey was administered from November 2004 to February 2005, about 2 years after the introduction of the waiver program. A total of 1,229 producers responded to the survey $(24 \%$ response rate), including 408 (32\%) from the orchard group and 821 (22\%) from the nonspecific group. Except for the analyses of orchard practices (tables 1 and 3), the results presented here apply to the combined 1,229 respondents.

The survey population adequately reflected the diversity of land tenure, operation size, commodity types and operator characteristics (as measured by the USDA National Agricultural Statistic Service's [NASS] Agricultural Census) in the nine counties. To further validate our survey, we conducted follow-up telephone interviews of mail survey nonrespondents in seven of the nine original counties, which targeted 1,078 nonrespondents for whom telephone numbers could be found. Of these, $44.7 \%$ were determined as owners of irrigated land and thus eligible for the survey, $16.2 \%$ were considered ineligible (mostly out of business) and $39.1 \%$ could never be reached.

A total of 300 nonrespondents were interviewed by telephone, and the results suggest that the mail survey respondents were more likely to own instead of lease their land and to have slightly higher rates of participation in the coalition groups. This means that we do not have a complete picture of the least-engaged producers, and reflects the difficulty of communicating with smaller and part-time producers. However, the survey does sufficiently represent the economically and politically significant segment of producers who will have the most influence on policy decisions and eventually, the behavior and attitudes of less active producers.

\section{Importance of local networks}

Communication frequency and trust in contacts. We asked producers about the number of times they had contacted different organizations in the last year, as well as the average level of trust that they had in these organizations based on an 11-point Likert scale (fig. 2). In the case of the Conditional Waiver, the Regional Board is considered the most important regulatory agency because it has the authority to manage and enforce the program. The diffusion network consists mostly of local agencies that deliver information about policies and practices to individual producers, as well as the regional organizers of the SVWQC. The agricultural commissioners are considered a diffusion agency because despite having formal regulatory duties, they are usually viewed as ombudsmen who help producers comply with pesticide laws.

The diffusion network agencies received much higher levels of trust and contact (e.g., $58 \%$ of respondents contacted agricultural commission- 

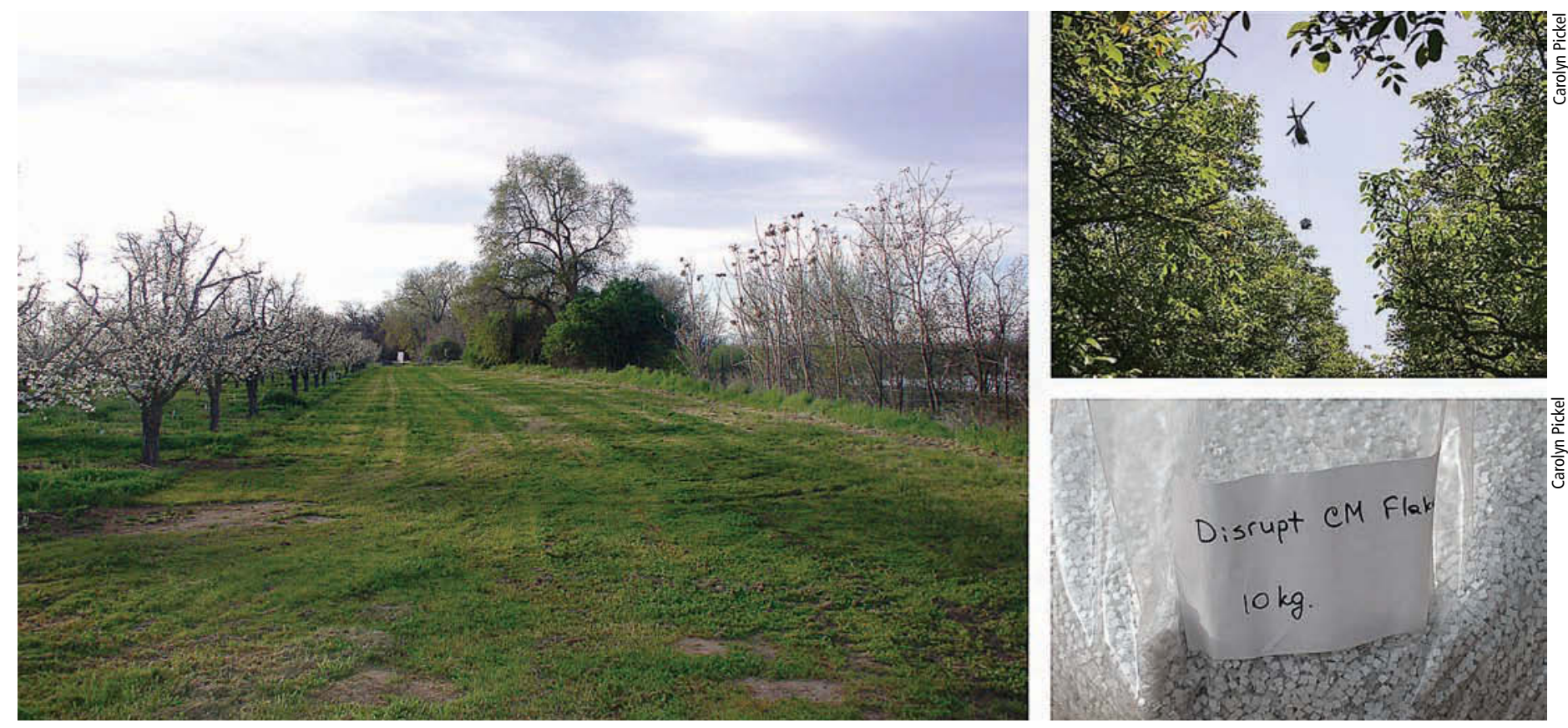

In 2004, about $\mathbf{5 0 \%}$ of Sacramento River Valley orchard growers surveyed were using, left, vegetated strips to filter and reduce runoff and lessen spray drift from their fields to nearby waterways. Only about $18 \%$ had adopted pheromone mating disruption to control various insect pests; right bottom, Hercon pheromone flakes, used to disrupt insect mating, are applied by helicopter, right top.

ers at least once) than the regulatory agencies ( $15 \%$ contacted the Region 5 board at least once) (fig. 2). Trust and contact were also positively correlated. Even diffusion agencies with fairly low levels of contact, such as the California Department of Food and Agriculture (15\% of farmers contacted at least once) and two of the regional coalition organizers (CURES and Ducks Unlimited [ $10 \%$ and $14 \%$ contacted at least once, respectively]), had higher levels of trust than might be expected, given their lower frequency of contact by growers. Just the basic descriptive data about trust and contact shows how the local diffusion network interacts most effectively with farmers with respect to water-quality management.

Explaining policy satisfaction, participation and practice adoption. We conducted a series of regression analyses to estimate how many times a grower would need to have contact with the diffusion network before leading to a change in three dependent variables associated with successful water-quality management: (1) participation in coalition activities; (2) satisfaction with coalition group policies; and (3) the number of orchard BMPs on a particular farm. The participation measure was a count (range $=0-9$ ) of the number of watershed activities producers had engaged in, varying in intensity from reading brochures to committee membership.
The satisfaction measure took the average level of agreement to four questions (on a 7-point scale, where 1 = strongly agreed and $7=$ strongly disagreed) about coalition effectiveness for addressing water-quality problems, encouraging the participation of other producers, pooling resources and facilitating BMP adoption. The orchard BMP measure was a count of 11 (range $=0-11$ ) different practices considered to be protective of water quality.

Measuring network density and control variables. To measure the density of network contacts, we counted the number of organizations contacted by the producer from the diffusion network (range $=0-14$ ) and the regulatory network (range $=0-6$ ). The analysis controlled for a range of other variables that are considered by diffusion-ofinnovation models, which are typically used to predict the adoption of agricultural practices. These variables included the producer's education level, their operation's income and the total number of acres farmed (rented plus owned). For the nonorchard sample, we measured perceptions about the severity of water-quality problems, the likelihood that agricultural sources are causing a problem, and the availability of information about the coalition groups. Due to nonresponse on the attitude and belief questions, multiple imputation by chained equations (MICE) was used to estimate missing data on these variables (see www.multiple-imputation.com for methodological details). For the orchard sample, we asked if the respondent was aware that pesticides have been detected in the Sacramento River and if they have been informed of water-quality management practices (table 1).

Adoption of best practices. Before reporting the results of the regression analysis, we summarize the rates of practice adoption (table 1). The results suggest that adoption rates partly reflect the combination of experience with each practice and the balance between economic risks/costs to crops and environmental protection. For example, some of the conventional pest-management practices, such as basing the time of spraying on weather/wind (reported by $88.4 \%$ of orchard growers), have been a part of agricultural research and education since the 1960s, and more is known about how to adapt these practices to specific farm settings to protect water quality while simultaneously controlling pests and reducing overall input costs ( $\mathrm{O}^{\prime}$ Connor-Mayer 2000).

Alternative pest-management practices, such as providing beneficial insect habitat (reported by 30.8\% of the orchard growers), on the other hand, are relatively new and are more complex in terms of their research development and adaptation to on-farm use. There is more uncertainty about their readiness for 
TABLE 2. Regression models for policy satisfaction and coalition participation*

\begin{tabular}{|c|c|c|}
\hline \multirow[b]{2}{*}{ Independent variables } & \multicolumn{2}{|c|}{ Dependent variables } \\
\hline & Policy satisfaction & Coalition participation \\
\hline \multicolumn{3}{|l|}{ Policy network exposure } \\
\hline Diffusion network & $0.05(0.02) \dagger$ & $0.27(0.02) \dagger$ \\
\hline Regulatory network & $-0.02(0.04)$ & $-0.06(0.06)$ \\
\hline \multicolumn{3}{|l|}{ Operation/operator characteristics } \\
\hline Education & $-0.06(0.03) \dagger$ & $0.07(0.04) \ddagger$ \\
\hline Income & $0.03(0.02)$ & $0.11(0.03) \dagger$ \\
\hline Total acres (100s) & $0.002(0.001)$ & $-0.002(0.002)$ \\
\hline \multicolumn{3}{|l|}{ Water-quality attitudes and beliefs } \\
\hline Perceived severity of water-quality problems & $0.01(0.03)$ & $-0.07(0.04) \ddagger$ \\
\hline Perceived likelihood of agricultural causes & $0.07(0.03) \dagger$ & $0.01(0.04)$ \\
\hline Coalition group information availability & $0.25(0.04) \dagger$ & $0.02(0.04)$ \\
\hline \multicolumn{3}{|l|}{ Other parameters } \\
\hline Constant & $3.64(0.20) \dagger$ & $1.85(0.26) \dagger$ \\
\hline Model fit & Adj. $R^{2}=0.11, F=16.84 \dagger$ & Adj. $R^{2}=0.21, F=36.58 t$ \\
\hline \multicolumn{3}{|c|}{$\begin{array}{l}\text { * Cell entries are estimates of unstandardized linear regression slope coefficients, } \\
\text { with standard errors in parentheses. }\end{array}$} \\
\hline
\end{tabular}

use, and about balancing their efficacy at reducing pests and associated crop risks with their environmental benefits (Kogan 1998).

Respondents reported moderate adoption rates of runoff-control practices, such as filter strips (reported by $50 \%$ of orchard growers). These practices are thought to pose few economic risks to crops, but to have fairly clear benefits for reducing the amount of agricultural contaminants entering surface water from dormant-season orchard sprays (Zalom et al. 2002). An exception is that orchard floor vegetation, depending upon how it is managed, influences orchard temperatures and may increase the potential for freeze damage in orchard crops (Snyder and Connell 1993).

Network contacts needed for change. Tables 2 and 3 summarize the results of the regression analysis by presenting unstandardized coefficients, which are interpreted as the expected change in the dependent variable (for example, policy satisfaction) for a one-unit change in an independent variable (for example, number of diffusion network contacts), controlling for the other independent variables. Diffusion networks have an important influence on all three dependent variables; the estimated diffusion network coefficients are positive and are statistically different from zero in all models (tables 2 and 3).

Unlike correlation coefficients, regression coefficients are not constrained to the range between negative and positive one $(-1$ to +1$)$; their importance must be judged relative to the scales of the variables. To assess their influence on each dependent variable, it is useful to calculate how many additional diffusion network contacts are required to increase the dependent variables by one unit. The fewer the contacts needed, the ing the relevant outcome.

In our survey, we found that the number of contacts needed to change different measures of policy effectiveness was highest for satisfaction with coalition group policies - it takes 20 diffusion network contacts to increase policy satisfaction by 1 point on the 7-point scale. However, the influence of diffusion networks was quite strong for coalition participation and BMP adoption. It took 9.0 additional diffusion network contacts for the adoption of an additional orchard BMP, and 3.7 contacts for another act of coalition participation. Overall, diffusion networks had the strongest influence on coalition group participation, followed by BMP adoption, and weakest (but still significant) for policy satisfaction. Contact with the regulatory network, on the other hand, had zero influence on the three dependent variables.

Other variables. The coefficients for the other independent variables — such as operator characteristics and attitudes and beliefs toward water quality - were largely consistent with classic diffusion-of-innovation models (Rogers 2003). Producers who thought that agriculture influences water quality and who had information about coalition group practices had higher levels of policy satisfaction. Producers who had more education more power each contact has for chang-
TABLE 3: Regression model for orchard environmental best management practices*

\begin{tabular}{|c|c|}
\hline $\begin{array}{l}\text { Independent } \\
\text { variables }\end{array}$ & $\begin{array}{c}\text { Unstandardized } \\
\text { coefficients }\end{array}$ \\
\hline \multicolumn{2}{|c|}{ Policy network exposure } \\
\hline Diffusion network & $0.11(0.04) \dagger$ \\
\hline Regulatory network & $0.01(0.09)$ \\
\hline \multicolumn{2}{|c|}{ Operation/operator characteristics } \\
\hline Education & $0.03(0.06)$ \\
\hline Income & $0.14(0.05) \dagger$ \\
\hline Total acres (100s) & $0.004(0.004)$ \\
\hline \multicolumn{2}{|c|}{ Water-quality attitudes and beliefs } \\
\hline Pesticide awareness & $0.65(0.22) \dagger$ \\
\hline Practices awareness & $0.70(0.27) \dagger$ \\
\hline \multicolumn{2}{|l|}{ Other parameters } \\
\hline Constant & $2.94(0.33) \dagger$ \\
\hline Model fit & Adj. $R^{2}=0.22, F=14.48 \dagger$ \\
\hline \multicolumn{2}{|c|}{$\begin{array}{l}\text { * Cell entries are estimates of unstandardized linear } \\
\text { regression slope coefficients, with standard errors } \\
\text { in parentheses. } \\
\text { † Reject null hypothesis of coefficient }=0 \text { at } P<0.05 \text {. }\end{array}$} \\
\hline
\end{tabular}

and higher incomes were more likely to participate, and higher income producers also had implemented more BMPs. Because there was a strong correlation between agricultural income and size of operation, the total-acres variable became significant in regressions that omitted the income variable. This suggests that larger and wealthier operations were more likely to participate in watershed management and to adopt BMPs. Orchard growers who were aware of pesticide problems and practices were also more likely to implement BMPs.

The most incongruous finding was that producers who thought that water quality is not a problem were more likely to participate in the coalition group activities, and more-educated growers were less satisfied with coalition policies. This suggests that an important motivation for participation by educated growers was to prevent the implementation of costly new policies for water-quality problems, which many producers perceived to be of lesser importance than other issues, such as urbanization. According to our personal interviews (see below), this type of "policy skepticism" is likely to shift toward problem-solving if waterquality monitoring conducted by the coalition clearly establishes a relationship between agricultural practices and water pollution.

\section{Networks enhance sustainability}

Agricultural water-quality management is an important example of sustainability in action. Our empirical analyses of grower attitudes and behaviors 
demonstrate that local diffusion networks enhanced the effectiveness of the SVWQC. The more producers interacted with diffusion networks, the more likely they were to be satisfied with watershed management policies, participate in policy activities and adopt environmentally sound management practices, as long as they were cost effective.

To further validate our results, we conducted on-farm, personal interviews with more than 20 Sacramento River Valley producers involved with waterquality management. The following quotes illustrate the pathways that are essential to promoting sustainability:

- "The coalitions are good to have because not only do they get the opinions of everybody, but they also provide for accurate information dissemination." - Glenn County producer, on information diffusion

- "Through the coalition group we've had very good success because people know that we're part of the community, that we're not there to control them, but to help them. They trust me better than they do the guy in Sacramento." - Shasta County producer, on social capital

- "People are resistant to change and may not be convinced that change is needed. Part of the job of the coalitions is outreach. There will be friction between growers but people will change their minds by talking to neighbors and seeing the practices work." - Glenn County producer, on cultural change

We feel that these findings are strong enough to emphasize to policymakers the importance of recognizing how government decisions can weaken or strengthen these local diffusion networks. Any dismantling of diffusion networks represents a loss of human and social capital, and capacity for cultural change, which severely degrades the ability to integrate sustainability principles into agricultural policy and decision-making.

A variety of evidence suggests that recent policies have decreased the investment in such networks. For example, California agricultural commissioners are local agencies that perform a variety of programs and duties in each county.
Historically, their core programs have included pesticide-use enforcement, quarantine, pest detection, pest exclusion, weights and measures programs, and outreach. In recent years, some noncore programs of the agricultural commissioners' offices have extended into land-use planning and natural resources management. In our survey, the agricultural commissioners were identified as the most trusted and most frequently contacted source for information about water quality. However, while their noncore programs and duties have expanded, funding sources have generally failed to keep pace with new programs and responsibilities, including water quality (personal communication, $\mathrm{M}$. Black, Glenn County agricultural commissioner, March 2007).

Another example is that the two main federal funding sources for landgrant university agricultural outreach programs - Agriculture Experiment Stations (1887 Hatch Act) and the Cooperative Extension system (1914 Smith-Lever Act) - increased by only $4.8 \%$ and $1.6 \%$, respectively, from 1996 to 2006, whereas costs inflated at a much higher rate. Although the full impact of these flat budgets depends on state and local decisions, they have contributed to significant decreases in local diffusion networks in California and

\section{References}

Brown BJ, Hanson ME, Liverman DM, Merideth RW. 1987. Global sustainability: Toward definition. Environ Manage 11(6):713

Chiffoleau Y. 2005. Learning about innovation through networks: The development of environmentfriendly viticulture. Technovation 25(10):1193-204.

Conley T, Udry C. 2001. Social learning through networks: The adoption of new agricultural technologies in Ghana. Am J Agri Econ 83(3):668-73.

[CVRWQCB] Central Valley Regional Water Quality Control Board. 2007. Discharges from Irrigated Lands. www.swrcb.ca.gov/rwqcb5/programs/irrigated_lands. Dillman DA. 2000. Mail and Internet Surveys: The Tailored Design Method. New York: J Wiley. $464 p$. Evenson RE, Gollin D. 2003. Assessing the impact of the Green Revolution, 1960 to 2000. Science 300(5620):758-62.

Henrich J. 2001. Cultural transmission and the diffusion of innovations: Adoption dynamics indicate that biased culture transmission is the predominate force in behavioral change. Am Anthropol 103(4):992-1013.

Kogan M. 1998. Integrated pest management: Historical perspectives and contemporary developments. Ann Rev Entomol 43:243-70.

O'Connor-Mayer PJ. 2000. The Safe and Effective Use of Pesticides (2nd ed.). UC Statewide Integrated Pest Management Project. ANR Pub 3324. 342 p. several important agricultural states. Likewise, from 2002 to 2004, California lost 152 county Cooperative Extension positions in 20 different counties. A final example is federal Farm Bill policies that influence local funding for the Environmental Quality Improvement Program (EQIP), which is administered throughout the United States by the Natural Resources Conservation Service and in conjunction with local resource conservation districts.

This analysis has limits as a case study in sustainability. The Conditional Waiver program in California is still too new to have achieved long-term success, has a relatively limited geographic scope and focuses mostly on the environmental aspects of sustainability. However, local diffusion networks will continue to be important to the future of these programs in California; they will also play a central role wherever sustainability involves policies that require innovation, collective action and cultural change.

\section{Lubell is Associate Professor, Department of Environmental Science and Policy, UC Davis; and A. Fulton is Irrigation and Water Resources Advi- sor, UC Cooperative Extension, Tehama, Glenn, Colusa and Shasta counties. The Russell Sage Foundation and California Policy Research Center funded this study.}

Ostrom E. 1994. Constituting social capital and collective action. J Theor Pol 6(4):527-62.

Putnam RD. 2000. Bowling Alone: The Collapse and Revival of American Community. New York: Simon Schuster. $541 \mathrm{p}$

Richerson PJ, Boyd R. 2005. Not by Genes Alone: How Culture Transformed Human Evolution. Chicago: Univ Chicago Pr. 342 p.

Rogers E. 2003. Diffusion of Innovations. New York: Free Pr. 576 p

Sabatier PA, Focht W, Lubell M, et al. (eds.) 2005. Swimming Upstream: Collaborative Approaches to Watershed Management. Cambridge, MA: MIT Pr. 327 p

Schaller N. 1993. The concept of agricultural sustainability. Agri Ecosys Environ 46(1-4):89.

Scheuring AF. Science and Service: A History of the Land Grant University and Agriculture in California. ANR Pub 3360. 260 p.

Snyder RL, Connell JH. 1993. Ground cover height affects pre-dawn orchard floor temperature. Cal Ag 47(1):9-12.

Zalom FG, Oliver W, Wallender WW, et al. 2002. Monitoring and mitigating offsite movement of dormant spray pesticides from California orchards. Acta Hort 592:729-35. 